\title{
GAYA BAHASA RETORIS DAN KIASAN DALAM KARYA LIMA PENYAIR ANAK DAN PEMANFAATANNYA SEBAGAI BAHAN AJAR SASTRA DI SMP
}

\author{
Afni Nur Akmalia, Dian Hartati, M. Januar Ibnu Adham \\ Universitas Singaperbangsa Karawang \\ Email: afni.nurakmalia@gmail.com,dian.hartati@ fkip.unsika.ac.id, \\ m.januar.ibnuadham@fkip.unsika.ac.id
}

\begin{abstract}
Abstrak: Penelitian ini bertujuan untuk mendeskripsikan (1) gaya bahasa retoris dalam karya lima penyair anak; (2) gaya bahasa kiasan dalam lima karya penyair anak; dan (3) pemanfaatan hasil analisis sebagai bahan ajar sastra anak dalam pembelajaran sastra di tingkat sekolah menengah pertama. Penelitian ini merupakan penelitian kualitatif dengan pendekatan stilistika. Sumber datanya adalah lima antologi karya penyair anak, yaitu (1) Resep Membuat Jagat Raya karya Abinaya Ghina Jamela, (2) Mata Air Surga karya Aulia Murti, (3) Guru Matahari karya Abdurahman Faiz, (4) Teman Kecil karya Rarai Masae Soca Wening Ati, dan (5) Hikayat Anakanak Pendosa karya Muhammad de Putra. Adapun teknik pengumpulan data yang digunakan adalah teknik dokumentasi. Analisis data dilakukan melalui pemrosesan satuan, kategorisasi, dan penafsiran data. Hasil penelitian adalah sebagai berikut (1) ada 53 data gaya bahasa retoris dari 12 jenis yang didominasi oleh gaya bahasa aliterasi sebanyak 20\%; (2) ada 80 data gaya bahasa kiasan dari 11 jenis yang didominasi oleh metafora hidup sebanyak 23\%; (3) hasil dari analisis gaya bahasa dalam karya lima penyair anak dapat dipertimbangkan menjadi bahan ajar pembelajaran sastra di tingkat SMP.
\end{abstract}

Kata Kunci: gaya bahasa, retoris, kiasan, puisi anak, sastra anak.

\section{RHETORICAL AND FIGURATIVE LANGUAGE STYLES IN THE WORKS OF FIVE CHILD POETS AND UTILIZATION AS LITERARY TEACHING MATERIALS IN JUNIOR HIGH SCHOOL}

\begin{abstract}
This study aims to describe (1) the rhetorical language style in the works of five child poets; (2) figurative language style in five works of child poets; and (3) using the results of the analysis as literary teaching materials for children in literature learning at the junior high school level. This research is a qualitative research with a stylistic approach. The data sources are five anthologies by children's poets, namely (1) "Resep Membuat Jagad Raya" by Abinaya Ghina Jamela, (2) "Mata Air Surga" by Aulia Murti, (3) "Guru Matahari" by Abdurahman Faiz, (4) "Teman Kecil" by Rarai Masae Soca Wening Ati, and (5) "Hikayat Anak-anak Pendosa" by Muhammad de Putra. There is also the data collection technique used is the documentation technique. Data analysis was performed through unit processing, categorization, and data interpretation. The results of the study are as follows (1) there are 53 rhetorical language style data from 12 types which are dominated by alliterative language styles as much as 20\%; (2) there are 80 data on figurative language styles from 11 types which are dominated by life metaphors as much as $23 \%$; (3) the results of the language style analysis in the works of 5 child poets can be considered as literature learning at the junior high school level.
\end{abstract}

Keywords: language style, rhetoric, figurative, children's literature, children's poetry.

BASASTRA Jurnal Bahasa, Sastra, dan Pengajarannya

Volume 9 Nomor 1, April 2021, P-ISSN 2302-6405, E-ISSN 2714-9765 


\section{PENDAHULUAN}

Seperti puisi orang dewasa, puisi anak memiliki jenis yang beragam baik dari segi tema maupun bentuk. Menurut Sarumpaet (2010: 26), sajaksajak untuk anak sangat beragam dan yang utama adalah mereka dapat mempersoalkan mulai dari hal-hal yang remeh, lucu, kehidupan sehari-hari, tentang alam, masa silam, impian, sampai rasa takut, dan sebagainya. Beberapa bentuk puisi tersedia bagi anak-anak, misalnya sajak bebas, sajak-sajak yang ditemukan dalam buku bacaan bergambar, sajak konkret, puisi naratif, serta puisi lirik.

Anak-anak yang memiliki ketertarikan dan keseriusan dalam menulis puisi dikenal masyarakat umum sebagai penyair anak. Sebutan lain yang juga dikenal ialah penyair cilik. Definisi dan batasan usia anak penting untuk diketahui peneliti dan pembaca agar penelitian ini dalam frekuensi pemahaman yang sama.

Merujuk pada UU Nomor 35 Tahun 2014 tepatnya pada Pasal 1 Ayat 1 menyatakan bahwasannya anak adalah seseorang yang belum berusia 18 (delapan belas) tahun, termasuk anak yang masih dalam kandungan. Dengan adanya perundang-undangan tersebut, kategori anak yang dikatakan sebagai penyair ialah seorang anak yang usianya di bawah 18 tahun dan memiliki karya cipta puisi. Maka, bagi peneliti istilah penyair anak yang lebih tepat dibandingkan penyair cilik.
Berdasarkan data temuan di lapangan, terjaring sepuluh penyair anak yang mewarnai sejarah puisi anak di Indonesia. Nama-nama penyair tersebut secara berurutan yaitu Sherly Malinton, Abdurahman Faiz, Zeffa Yurihana, Utomo Soconingrat, Soeryadarma Isman, Aulia Murti, Rarai Masae Soca Wening Ati, Muhammad de Putra, Abinaya Ghina Jamela, Muhammad Iqbal Althafa. Para penyair yang berusia sekitar 6-16 tahun tersebut memiliki karya antologi puisi yang telah dibukukan dan dipublikasikan ke media massa.

Berkaitan dengan bertambahnya penyair anak dan karyanya sebagaimana data di atas, sejatinya Indonesia sangat berpotensi memiliki lebih banyak lagi penyair anak yang melahirkan karya. Hal itu dibandingkan dengan luasnya wilayah dan banyaknya jumlah anak di Indonesia. Puluhan tahun puisi anak telah membersamai namun apresiasi terhadap karya penyair anak masih belum maksimal. Gegap gempita anakanak terhadap kegiatan cipta puisi yang sudah ada seharusnya selaras dengan penyampaian karya hingga benar-benar sampai kepada pembaca anak-anak.

Kurangnya apresiasi terhadap sastra anak serta minimnya karya penyair anak yang dijadikan referensi puisi untuk anak-anak juga menimbulkan persoalan lain. Minimnya karya penyair anak sebagai referensi bacaan mengakibatkan anak kesulitan memahami isi puisi bahkan 
merasa asing dengan puisi. Selain itu, referensi puisi yang sudah ada umumnya terlalu berat (dewasa) juga menurunkan minat anak terhadap puisi.

Adapun praktik dan proses berpuisi di sekolah, siswa lebih banyak melakukan aktivitas secara lisan dibandingkan tulis. Semestinya kedua aktivitas tersebut diseimbangkan agar tidak ada kegiatan yang dilewatkan siswa. Kemudian sepulang sekolah, praktik anak dalam berpuisi seolah terjeda karena lingkungan yang kurang mendukung anak untuk akrab dengan puisi.

Perlunya kajian ilmiah sebagai penghubung antara penyair anak, karya, dan pembaca anak-anak menjadi alasan peneliti untuk menganalisis lima karya penyair yang termasuk dalam daftar sepuluh penyair anak pada pembahasan sebelumnya, yaitu: Muhammad de Putra, Rarai Masae Soca Wening Ati, Abdurahman Faiz, Aulia Murti, dan Abinaya Ghina Jamela. Alasan dipilihnya lima penyair anak tersebut karena kelimanya cukup mewakili karya penyair anak berdasarkan rentang usia dari 7 tahun hingga 16 tahun. Perpaduan usia penyair anak dan pengalaman literasinya memengaruhi diksi dan gaya bahasa yang tertuang dalam puisi.

Menurut Mulyana dalam buku Pradopo (2014: 94) menyatakan, gaya bahasa adalah susunan perkataan yang terjadi karena perasaan yang timbul atau hidup dalam hati penulis, yang menimbulkan suatu perasaan tertentu dalam hati pembaca. Sebuah puisi hanyalah teks, sekadar kata-kata biasa karena tidak ada nyawa (gaya bahasa) di dalamnya. Namun, ketika penulis menghidupkan puisi dengan imaji serta gaya bahasa, maka puisi terasa bernyawa.

Secara lebih spesifik, analisis yang dilakukan terhadap karya lima penyair anak tersebut yaitu berfokus pada gaya bahasa retoris dan kiasan. Gaya bahasa tersebut berdasarkan pada langsung tidaknya makna yang terdapat dalam puisi. Sebagaimana kategori gaya bahasa menurut Keraf (2010: 129) yang terbagi menjadi dua, yaitu retoris dan kiasan.

Gaya bahasa yang dikategorikan berdasarkan langsung tidaknya makna mengacu pada makna denotatif dan konotatif. Apabila bahasa suatu teks (puisi) acuannya mempertahankan makna dasar dan struktural, maka bahasanya bermakna denotatif yang berarti termasuk dalam gaya bahasa retorika atau retoris. Jika bahasa dalam puisi ditemukan menyimpang, maka bahasanya mengandung makna konotatif dan dikategorikan sebagai gaya bahasa kiasan. Adapun pembagian masing-masing gaya bahasa terdiri dari beberapa jenis. Gaya bahasa retoris terdiri dari 23 jenis, sedangkan kiasan terdiri dari 21 jenis.

Gaya bahasa termasuk unsur stile yang terdapat dalam wilayah stilistika bersama dengan citraan. Stilistika juga dapat digunakan dalam menganalisis bahasa ilmiah dan sastra. Dalam penelitian ini, stilistika digunakan untuk menganalisis bahasa sastra khususnya gaya bahasa retoris dan 
kiasan yang digunakan oleh lima penyair anak.

Kajian stilistika bermanfaat dalam dunia sastra baik fungsi maupun makna estetiknya seperti yang dikemukakan oleh Wellek \& Warren (2016: 206) bahwa manfaat stilistika yang sepenuhnya bersifat estetis, membatasi lingkup bidang ini khusus untuk studi karya sastra dan kelompok karya yang dapat diuraikan fungsi dan makna estetisnya.

Penelitian ini sejalan dengan penelitian yang dilakukan oleh Rachmadani (2017), mahasiswa Pendidikan Bahasa Dan Sastra Indonesia Universitas Negeri Yogyakarta dengan judul "Analisis Penggunaan Gaya Bahasa pada Puisi Siswa SMA di Yogyakarta" yang meneliti penggunaan gaya bahasa pada puisi siswa SMA di Yogyakarta. Kebaruan dalam penelitian ini adalah menambahkan luaran atau output bahan ajar ke dalam rumusan masalah. Selain itu, peneliti mendeskripsikan temuan gaya bahasa secara denotatif dan konotatif ke dalam pembahasan.

Sehubungan dengan pemaparan di atas, peneliti tertarik untuk menggali gaya bahasa retoris dan kiasan yang terkandung dalam puisi lima penyair anak. Selain itu, peneliti juga memanfaatkan antologi puisi karya lima penyair anak dan hasil analisis sebagai bahan ajar materi teks puisi di tingkat SMP. Berdasarkan uraian di atas, peneliti mengambil judul "Gaya Bahasa Retoris dan Kiasan dalam Karya 5 Penyair Anak dan
Pemanfaatannya sebagai Bahan Ajar Sastra di Tingkat SMP”.

Tujuan dari penelitian ini yaitu mendeskripsikan (1) gaya bahasa retoris, (2) gaya bahasa kiasan yang ditemukan dalam karya lima penyair anak, (3) pemanfaatan hasil analisis sebagai bahan ajar sastra anak dalam pembelajaran sastra di tingkat SMP.

\section{METODE}

Berdasarkan tujuan penelitian, metode yang digunakan dalam penelitian ini adalah metode deskriptif kualitatif. Menurut Moleong (2007: 6), penelitian kualitatif adalah penelitian yang bermaksud untuk memahami fenomena tentang apa yang dialami subjek penelitian, misalnya perilaku, persepsi, motivasi, tindakan, dan lainlain, secara holistik dan dengan cara deskripsi dalam bentuk kata-kata dan bahasa, pada suatu konteks khusus yang alamiah dan dengan memanfaatkan metode alamiah.

Pendekatan objektif khususnya stilistika digunakan dalam penelitian ini guna mengeksplorasi unsur gaya bahasa retoris dan kiasan melalui analisis kebahasaan atau linguistik dalam puisi anak. Stilistika menurut Nurgiyantoro (2017: 90) adalah sebuah pendekatan (atau secara lebih konkret: metode, teknik) untuk mengkaji penggunaan bahasa dalam konteks dan ragam bahasa tertentu. Adapun subjek dari penelitian ini merupakan teks karya sastra, berupa teks puisi karya lima penyair anak yang termaktub dalam antologi milik masing-masing penyair, di antaranya yaitu: Resep 
Membuat Jagat Raya karya Abinaya Ghina Jamela; Mata Air Surga karya Aulia Murti; Guru Matahari karya Abdurahman Faiz; Teman Kecil karya Rarai Masae Soca Wening Ati; dan Hikayat Anak-anak Pendosa karya Muhammad de Putra. Teknik pengumpulan data yang digunakan adalah teknik dokumentasi. Sedangkan proses validasi data dilakukan dengan teknik analisis data yaitu pemrosesan satuan, kategorisasi, dan penafsiran data. Dua teks puisi dari lima penyair anak tersebut akan dianalisis sehingga total semua subjek datanya ialah 10 teks puisi. Adapun objek penelitian ini adalah gaya bahasa retoris dan kiasan dalam puisi-puisi yang sudah ditentukan.

Peneliti menggunakan bantuan instrumen dalam melaksanakan penelitian. Adapun pedoman analisis digunakan untuk menentukan objek yang dicari dalam teks puisi berdasarkan teori tentang gaya bahasa menurut Keraf (2010: 219) dan Prastowo (2012: 85) untuk pedoman penyusunan bahan ajar handout.

\section{HASIL DAN PEMBAHASAN}

Deskripsi dalam penelitian ini berupa analisis gaya bahasa retoris dan kiasan. Bait puisi yang mengandung gaya bahasa akan diberikan kode huruf $B$ dan angka. Misalnya $B 3$ yang berarti puisi bait ketiga. Sedangkan keterangan larik ditunjukkan dengan kode huruf $L$ yang disertai angka sebagai tanda urutan larik dalam suatu bait, misalnya L1 yang berarti larik pertama.

\section{Analisis Gaya Bahasa Retoris}

Beragam gaya bahasa retoris ditemukan dalam karya lima penyair anak. Beberapa di antaranya ialah aliterasi, erotesis, asonansi, anastrof, dan perifrasis.

\section{Aliterasi}

Aliterasi ditandai dengan banyaknya penggunaan huruf konsonan dalam satu kalimat. Tepatnya pada puisi Album Kenangan di Rumah Panggung karya Rarai Masai Soca Wening Ati terdapat kalimat yang terbentuk dari larik pertama (L1) hingga ketiga (L3) bait keempat (B4). Ditemukan kemunculan huruf konsonan $k$ yang repetitif. Pengulangan huruf konsonan tersebut memberikan kesan penegasan dan kejelasan ketika dibaca atau dilafalkan. Berikut kutipan dari larik yang mengandung aliterasi.

Aku angankan lagi tawa-gelak/ dalam permainan congklak (L1) petak umpet, atau ketikal membuat naga terjebak

dalam semak (L3)(B4)

Pada kutipan di atas dapat dilihat bahwa aku lirik sedang mengingat kembali kenangan tentang suasana ketika bermain congklak, petak umpet, atau permainan ular naga. Permainan congklak, petak umpet, dan sebagainya merupakan permainan yang umumnya dimainkan oleh anak-anak. Bermain dengan banyak teman di ruang terbuka ialah aktivitas yang sangat menyenangkan. Dari ungkapan aku lirik tersebut tersirat bahwa aku lirik sedang mengingat kenangan masa kecilnya yang sering bermain bersama 
teman-temannya. Ditambah lagi bunyi dari diksi yang diungkapkan terdengar harmoni karena keberadaan huruf konsonan $k$ yang repetitif.

\section{Erotesis}

Erotesis muncul dalam puisi para penyair anak, di antaranya terdapat dalam puisi Guru Matahari karya Abdurahman Faiz pada larik pertama dan di bait petama (B1) dengan kutipan /Siapakah guru para matahari?/ (L1). Kalimat "Siapakah guru para matahari?" tampak menjadi pembuka dari larik-larik berikutnya yang disampaikan oleh dia lirik. Kalimat tanya tersebut menunjukkan bahwa dia lirik seperti sedang berhadapan langsung dengan para pembaca dan menanyakan siapa orang yang mengajarkan para matahari. Sebagai pembaca, berbagai persepsi bermunculan mengenai seseorang dan para matahari yang ditanyakan oleh dia lirik.

Berdasarkan ciri erotesis, kalimat “Siapakah guru para matahari?" Jelas memenuhi fungsi penekanan yang wajar namun tidak menghendaki jawaban. Dia lirik melayangkan pertanyaan tanpa jawaban yang tersurat dalam puisi. Pembaca terasumsi baik secara rasional dan emosional dan meyakini bahwa mengetahui jawaban dari pertanyaan retoris tersebut. Selain itu, bentuk erotesis tersebut memancing pembaca untuk lebih mendalami maksud dari puisi Guru Matahari.

Secara konotatif, pertanyaan retoris dari kalimat "Siapakah guru para matahari?" menyentuh sanubari pembaca tentang jasa seorang guru. Sebagaimana larik-larik selanjutnya sosok tersebut secara eksplisit diutarakan dia lirik. Setiap orang pasti pernah memiliki seorang guru. Guru sekolah, guru spiritual, guru bela diri, dan lain sebagainya. Ketika membaca puisi Guru Matahari pembaca memosisikan diri sebagai seorang murid yang mempunyai guru. Sehingga pada saat pertanyaan retoris tersebut dibaca, pikiran dan perasaan pembaca seakan langsung teringat pada jasa guru-gurunya.

Di sisi lain, ketika kalimat seperti "Siapakah guru para matahari?" termaktub dalam rangkaian puisi, tercermin pula suatu kondisi bahwa ada kesadaran yang selama ini hilang di antara pembaca. Kesadaran yang dimaksud seperti perasaan peduli, perhatian, peringatan, dan apresiasi terhadap guru. Puisi menjadi harapan dan titik balik untuk mengingatkan kembali apa yang dilupakan serta luput dari perhatian. Melalui diksi yang puitis, puisi melukiskan perjuangan dan kesungguhan guru dalam mendidik murid-muridnya. Puisi juga menjadi media untuk mengingat besar dan tulusnya pengabdian guru terhadap muridnya.

\section{Asonansi}

Gaya bahasa asonansi satu di antaranya terdapat dalam puisi Roti Lapis karya Abinaya Ghina Jamela. Puisi diawali dengan gaya bahasa asonansi yang ditandai dengan adanya pengulangan huruf vokal dalam satu 
kalimat. Pengulangan huruf vokal $a$ dan $i$ terdapat dalam larik pertama dengan kutipan /Ada pelangi di mulutku yaitu roti lapis/. Banyaknya huruf vokal $a$ dan $i$ yang muncul memberikan efek penegasan ketika dibaca atau dilafalkan. Dengan demikian, puisi tidak hanya mengedepankan keindahan bentuk, tetapi juga memperhatikan keindahan bunyi ketika dibacakan atau dilafalkan.

Sebagai larik pertama, aku lirik hendak menyampaikan pernyataan pembuka yang jelas dan tegas (asonansi) mengenai puisi Roti Lapis. $\mathrm{Aku}$ lirik menggambarkan indra pengecapannya ketika memakan roti lapis. Dengan bahasa yang mudah dipahami, aku lirik seolah memberikan kesan positifnya terhadap roti lapis sejak larik pertama.

\section{Anastrof}

Menurut Keraf (2010: 219), anastrof atau inversi yaitu gaya retoris yang ditandai dengan pembalikan posisi susunan kata yang biasa dalam kalimat. Gaya bahasa anastrof yang tersurat dalam larik keempat (L4) pada puisi Pintu Masuk karya Muhammad de Putra. Ditandai dengan frasa letih perjalanan yang menyimpang secara bentuk urutan diksinya.

Umumnya ungkapan tersebut berwajah perjalanan letih, namun dalam larik tersebut posisinya tampak terbalik. Kendati demikian, makna dari frasa tersebut tetaplah sama yaitu gambaran perjalanan yang menguras tenaga hingga terasa lelah sekali. Berikut ini rupa dari anastrof dalam larik keempat (L4) yaitu //dari letih perjalanan yang sedih lagi pedih/.

\section{Perifrasis}

Gaya bahasa perifrasis dalam pembahasan ini diwakili oleh temuan yang terdapat dalam puisi Merapi 2 karya Aulia Murti. Gaya bahasa retoris yang ditemukan pada puisi tersebut menggunakan kata lebih banyak dari yang diperlukan. Berlebihan yang dimaksud dalam gaya bahasa ini bukanlah hiperbola, melainkan karena kata-kata yang digunakan sejatinya dapat diganti dengan satu kata saja. Gaya bahasa dengan ciri-ciri tersebut merupakan gaya bahasa perifrasis. Kemunculan perifrasis terlihat dalam rangkaian larik pertama dan kedua bait ketiga (B3).

Pada larik kedua (L2) bait ketiga (B3), ditemukan klausa "Sujud ke Selatan dalam kesucian menghadapNya" yang memiliki makna denotasi dan konotasi. Makna denotasi dari klausa tersebut mengarah pada kondisi seseorang dalam puisi yang bernama Mbah Marijan. Dalam klausa tersebut, aku lirik menggambarkan kondisi Mbah Marijan yang bersujud mengarah ke selatan. Adapun frasa "dalam kesucian menghadap-Nya" mengarah kepada makna meninggal dunia. Maka, maksud dari ungkapan di balik gaya bahasa perifrasis ialah posisi Mbah Marijan yang meninggal dunia ketika bersujud.

Rangkaian peristiwa meletusnya Merapi dalam puisi juga merupakan peristiwa nyata yang terjadi pada bulan Oktober tahun 2010 yaitu peristiwa 
meletusnya Gunung Merapi, gunung teraktif di dunia yang terletak di antara Yogyakarta dan Jawa Tengah. Akibat dari peristiwa itu Mbah Marijan yang merupakan seorang juru kunci Gunung Merapi akhirnya wafat tergulung awan panas 'wedhus gembel' dengan posisi tubuh sedang bersujud menghadap ke arah selatan.

Hal yang menarik dari kutipan larik pertama (L1) dan kedua (L2) tersebut ialah diksi Selatan. Arti selatan menurut KBBI yaitu arah mata angin, sedangkan yang dimaksud oleh aku lirik dalam puisi Merapi 2 tampaknya bukan demikian. Aku lirik bahkan menggunakan huruf kapital untuk menyebut diksi Selatan. Ungkapan Selatan secara tidak langsung merepresentasikan Pantai Selatan di mana tempat Ratu Pantai Selatan atau Nyi Roro Kidul berada. Berdasarkan berita yang beredar sekitar tahun 2010, Mbah Marijan meninggal dunia karena tergulung awan panas dengan posisi badan bersujud ke selatan. Secara mistis hal itu dikaitkan dengan Nyi Roro Kidul.

Aku lirik secara tersirat menceritakan bahwa di sisi lain peristiwa gunung Merapi meletus, terdapat keganjilan tentang kabar kematian Mbah Marijan. Selanjutnya frasa "kesucian menghadap-Nya" juga menghasilkan pertanyaan di antara pembaca. Jika aku lirik menggambarkan Mbah Marijan meninggal dunia ketika bersujud ke Selatan, maka menghadap siapakah yang dimaksud aku lirik? Jawaban dari pertanyaan tersebut lebih mengarah kepada hal yang pasti, yaitu kepada Tuhan sebagaimana terwakili oleh 'Nya'. Berikut ini adalah kutipan lengkap larik yang mengandung perifrasis.

Mbah Marijan, juri kunci Merapi (L1)

Sujud ke Selatan dalam kesucian/ menghadap-Nya

(L2)(B3)

\section{Analisis Gaya Bahasa Kiasan}

Beragam gaya bahasa kiasan ditemukan dalam karya lima penyair anak. Beberapa di antaranya ialah metafora hidup, simile, personifikasi, metafora mati, dan sinisme.

\section{Metafora hidup}

Dari 10 karya lima penyair anak yang dianalisis, hanya dua puisi yang tidak mengandung metafora. Selebihnya puisi didominasi oleh metafora jenis ini. Satu di antaranya yaitu bentuk metafora yang terdapat dalam puisi Doa Sapi karya Muhammad de Putra.

Larik kedua dan ketiga (L2/L3) pada bait pertama (B1) mengandung metafora hidup. Dikatakan demikian karena terdapat frasa rumput-rumput kesedihan dari dua hal singkat yang dibandingkan secara langsung tanpa adanya kata sambung seperti dalam simile. Selain itu, frasa tersebut juga mengalami penyimpangan makna yang tidak umum sehingga dikategorikan sebagai metafora hidup (baru).

Diksi rumput-rumput lebih dikenal sebagai tanaman kecil yang tumbuhnya berkelompok dan sering kali disebut sebagai tanaman liar. 
Sedangkan diksi kesedihan dimaknai sebagai bagian dari perasaan manusia, yaitu perasaan sedih atau duka. Dua diksi tersebut berasal dari kutub makna yang berbeda namun dalam larik puisi digabungkan menjadi satu frasa. Jika membacanya dengan sepintas, maka makna yang tertangkap adalah rumputrumput yang bersedih. Namun tentu saja bukan itu makna yang sebenarnya ingin disampaikan kau lirik.

\section{Rumput-rumput}

kesedihan

dimaknai sebagai bentuk ungkapan dari sifat kesedihan itu sendiri yang memiliki ciri seperti rumput. Rumputrumput kesedihan menciptakan makna bahwa kesedihan atau kedukaan dapat tumbuh subur di mana saja seperti rumput liar. Kesedihan tidak hanya ada di satu tempat atau satu waktu, tetapi dapat menyebar, bahkan berkembang menjadi kesedihan yang lebih besar. Berikut ini merupakan kutipan larik bermetafor.

\section{rumput-rumput kesedihan dalam}

hati. Jadilah sapi engkau!/ Mouuuw,

Dari kutipan larik di atas, jelas terlihat bahwa begitu banyak dan semakin bertambahnya kesedihan di hati layaknya rumput liar yang subur. Kau lirik menggunakan perumpamaan rumput sebagai pembanding apa yang sebenar-benarnya kau lirik ingin sampaikan. Selain itu, kau lirik menggunakan diksi rumput sebagai upaya penyeimbang analogi yang dibangun sejak larik pertama yakni /Seperti sapi yang terus memakan/. Dikatakan demikian karena rumput termasuk dalam pakan sapi sehingga analogi-analogi dalam puisi masih memiliki keterkaitan satu sama lain.

\section{Simile}

Simile menjadi gaya bahasa kiasan yang dominan sebagaimana metafora. Puisi penyair anak tidak terlepas dari kehadiran simile. Di antaranya adalah simile yang terdapat pada puisi Mata Air Surga karya Aulia Murti. Tepatnya pada larik pertama dan kedua, simile ditandai dengan temuan kata sambung Adalah dalam kalimat Tangisan ibu Adalah mata air surga (L1/L2). Secara eksplisit aku lirik membandingkan tangisan ibu dengan mata air surga. Dua hal tersebut hakikatnya berlainan, namun seolah memiliki kesamaan.

Makna denotasi dari frasa tangisan ibu merujuk pada perbuatan seorang ibu yang menangis. Aku lirik memvisualisasikan seorang ibu melalui air mata (tangisan). Diksi tangisan sendiri berasal dari kata 'tangis' yang berarti ungkapan perasaan dengan mencucurkan air mata dan mengeluarkan suara. Perbuatan menangis dapat diartikan sebagai ekspresi sedih ataupun terharu. Air mata yang menetes merupakan wujud fisik dari stimulus perasaan yang ada di dalam hati seseorang yang menangis. Begitupula dengan suara ketika menangis, dapat terdengar tersedusedu, menjerit, atau merintih. Makna tangisan seseorang tergantung pada apa yang melatarbelakanginya menangis.

Makna konotatif dari frasa tangisan ibu pada puisi ialah kasih sayang seorang ibu. Kasih sayang yang 
bersifat abstrak diejawantahkan menjadi tangisan. Sebagaimana sebuah tangisan yang dilatarbelakangi oleh perasaan, kasih sayang ibu begitu tulus serta memberikan kehidupan bagi sekitarnya. Dengan kelembutan kasih sayang ibu, seorang anak berperangai baik dan hangat. Bahkan marahnya seorang ibu juga sebuah bentuk kasih sayang, karena tidak lain bertujuan untuk kebaikan anak-anaknya.

Ada masa ketika seorang ibu menangis disebabkan oleh perasaan sedih karena mungkin ada luka yang diberikan oleh anak baik disengaja maupun tidak. Ada pula masa ketika seorang ibu menangis haru karena bahagia atas anak-anaknya. Seorang ibu juga menangis sebagai bentuk syukur dan bangga, melihat anakanaknya meraih apa yang dicitacitakan. Tangisan ibu juga bermakna sebagai doa. Seorang ibu yang senantiasa mendoakan keluarganya tidak jarang diiringi dengan tangis air mata. Antara ibu, tangisan, dan air mata, ketiganya melebur menjadi satu sebagai kasih sayang yang tidak terhingga.

Adapun frasa mata air surga dalam puisi merupakan sebuah perumpamaan yang dibuat oleh aku lirik mewakili kasih sayang seorang ibu. Menurut definisi, mata air berarti sumber air yang keluar secara alami dari tanah atau batuan. Mata air umumnya sejuk, jernih, dan tidak pernah habis meskipun sering diambil airnya. Mata air sangat berperan penting dalam kehidupan mahluk hidup, tak terkecuali manusia. Manfaat mata air di antaranya yaitu sebagai sumber air minum, pengairan, sarana ibadah, dan lain-lain. Dengan kata lain, tidak ada satu pun kejelekan dari mata air kecuali untuk kebermanfaatan atau kebaikan.

Makna surga secara denotatif ialah alam akhirat untuk roh manusia terpilih yang akan tinggal untuk selama-lamanya. Surga ialah cita-cita, akhir perjalanan, ujung kehidupan yang abadi. Keindahan surga melebihi kiasan keindahan apa pun yang ada di bumi (dunia). Justru sebaliknya, surga sering dijadikan sebagai perumpamaan ketika takjub dan membayangkan keindahan tiada banding. Surga dalam istilah religius merupakan tempat yang dijanjikan Tuhan kepada hambanya yang beriman dan taat.

Melihat definisi mata air dan surga, frasa mata air surga mewakili kasih sayang seorang ibu karena terdapat keterkaitan antara ibu dan mata air surga. Sosok ibu merupakan sumber kehidupan bagi manusia di dunia. Setiap manusia dilahirkan dari rahim ibu setelah dikandung selama kurang lebih sembilan bulan lamanya. Hingga pada akhirnya anak-anak yang lahir dari ibu tersebut mengulang kembali proses kehidupan. Ibu juga berperan sebagai madrasah pertama bagi anak-anaknya dan memberikan kasih sayang yang lembut serta tulus. Ungkapan "surga di bawah telapak kaki ibu" menjadi bukti betapa mulianya seorang ibu. Kasih sayang ibu juga dikatakan sebagai kasih sayang Tuhan. Hal itu karena Tuhan 
menjanjikan surga bagi anak yang berbakti kepada ibunya (orang tua).

Sekilas frasa mata air serupa dengan air mata. Air mata berkonotasi pada hal-hal yang menyedihkan, sedangkan mata air mengantarkan imajinasi pembaca kepada hal yang suci dan bermanfaat. Sebagaimana mata air surga yang diungkapkan aku lirik, maknanya positif dan menyegarkan.

\section{Personifikasi}

Puisi Merindukan Rumah mengandung gaya bahasa kiasan, di antaranya ialah gaya bahasa personifikasi yang penggunaannya dalam puisi paling mendominasi. Personifikasi pertama ditemukan pada bait pertama (B1). Berikut ini merupakan kutipan yang mengandung personifikasi.

Sebuah ayunan mengajakku/
bercerita

Tentang pagi hari dan album/ kenangan $\quad(L 2)(B 1)$

Pada kutipan larik di atas, terdapat penginsanan suatu benda yang dibuktikan dengan diksi ayunan yang bercerita kepada aku lirik. Seperti yang diketahui secara umum, ayunan ialah benda mati yang digunakan sebagai mainan atau wahana bagi anak-anak. Begitu pula dengan berbicara yang berarti kemampuan seorang manusia dalam mengatakan atau menyampaikan sesuatu. Sedangkan dalam kutipan larik di atas, ayunan seolah menjadi pencerita atau seseorang yang dapat berbicara dengan baik.
Dari bentuk personifikasi tersebut dapat digambarkan bagaimana kesepian melanda aku lirik sehingga tidak ada satu orang pun yang bisa diajak aku lirik untuk bertukar cerita. Kesepian yang aku lirik rasakan diluapkan pada dirinya sendiri ketika berada dalam ayunan. Interaksi antara ayunan dan aku lirik menjadi awal mula perasaan rindu diungkapkan pada bait-bait selanjutnya.

Personifikasi juga terdapat dalam larik pertama dan kedua pada bait kedua (B2). Ditandai dengan adanya diksi membuka sebagai tindakan yang dilakukan oleh matahari. Dua diksi tersebut memiliki makna denotatif yang berlawanan, namun penggabungan dari keduanya dapat mengaktifkan imajinasi pembaca. Diksi membuka merupakan sesuatu yang biasa dilakukan oleh manusia. Matahari yang merupakan benda langit diimajinasikan dapat membuka sesuatu sehingga tercipta makna kiasan. Berikut ini ialah kutipan larik yang mengandung personifikasi bentuk kedua.

Matahari yang baru saja muncul (L1)

membuka tangga cahayanya (L2)(B2)

Makna yang tersirat dari kutipan di atas ialah harapan yang terbuka lebar kepada aku lirik. Pada kutipan di atas juga terdapat frasa tangga cahayanya yang secara denotatif berarti tangga yang bercahaya. Apabila dikaitkan dengan matahari, tangga cahaya serupa jalan menuju matahari atau menuju sesuatu yang sangat diagungkan. Selain 
itu tangga cahaya juga dapat dimaknai sebagai jalan menuju sesuatu yang tinggi dan istimewa melebihi keistimewaan apa pun di bumi.

Dalam realitas hidup, tangga cahaya tersebut dapat menjadi bumerang bagi seseorang yang hendak mencapainya. Hal itu dikarenakan cahaya adalah sesuatu yang tidak terjangkau oleh manusia. Manusia dapat mendambakan cahaya namun hendaknya tidak terobsesi menjadi cahaya tersebut karena akan berpotensi menjadi angkuh dan jumawa. Manusia pada umumnya menggantungkan harapan menjadi cahaya ialah sebagai kiasan. Tujuan sejatinya manusia ingin menebar manfaat sebagaimana cahaya yang menerangi gelap dan menghidupkan harapan bagi orang lain.

\section{Metafora Mati}

Metafora mati terdapat dalam puisi karya penyair anak, satu di antaranya terdapat dalam puisi berjudul Penyair karya Abdurahman Faiz. Berbeda dengan metafora pada temuan sebelumnya, metafora dikatakan mati karena dalam frasa yang mengandung metaforanya sudah tidak dapat ditentukan makna konotasinya lagi. Berikut ini ialah larik yang dimaksud.

Aku memahat kata-kata (L1) (B3)

Frasa memahat kata-kata pada larik di atas sama persis dengan frasa pada larik pertama di bait awal puisi. Dikarenakan kesamaan tersebut memiliki makna yang sama, maka frasa memahat kata-kata pada larik di atas tidak lagi menghasilkan makna baru sehingga disebut sebagai metafora mati. Bedanya, larik di atas bersubjek $A k u$ sedangkan pada bait pertama bersubjek Penyair. Sebagaimana penyair dewasa, aku lirik melakukan perlakuan yang sama terhadap katakata. Apabila larik di atas ditafsirkan secara utuh berikut subjeknya, tersirat makna bahwa aku lirik juga bersungguh-sungguh dalam menciptakan kata-kata ibarat seorang penyair anak yang mengeksplorasi diksi puisi serta kemampuan menulisnya dengan sepenuh hati. Di sisi lain, larik tersebut seperti sebuah pernyataan atau deklarasi diri bahwa seorang penyair anak pun tidak mainmain dalam merangkai puisi. Seorang penyair anak didasari oleh pengalaman literasi dan keluasan imajinasi. Karena kedua modal dasar tersebut, penyair anak mampu menuangkan ide atau kata-kata dari pikirannya ke dalam bentuk puisi.

\section{Sinisme}

Berdasarkan penelitian yang dilakukan terhadap puisi berjudul Kisah Sedih Tentang Telepon Genggam karya Abinaya Ghina Jamela (Naya), sinisme menjadi gaya bahasa kiasan yang paling banyak ditemukan dalam puisi ini. Ditandai dengan beberapa bait yang mengandung sindiran langsung tertuju pada objek yang disindir. Bentuk sindiran berupa ungkapan tentang keresahan aku lirik melalui diksi-diksi yang digunakan. Berikut ini merupakan kutipan puisi yang mengandung sinisme.

Telepon genggam dinyalakan/ pasar malam pun dibuka. (L1) 
Bunyi nyaring panggilan, warna-

/warni potret wajah,

variasi permainan, mereka asik/

sendiri.

Ibuku tak mau ketinggalan, ikut/ ambil bagian.

(L4)(B1)

Pada kutipan bait di atas, sinisme ditunjukan dengan penggambaran suasana tempat di mana aku lirik berada. Dari larik pertama (L1) /Telepon genggam dinyalakan, pasar malam pun dibukal aku lirik menceritakan suasana ketika pasar malam dibuka, orang-orang justru sibuk mengecek telepon genggam mereka, bukan menikmati keramaian di pasar malam yang baru dibuka. Sindiran pada larik sebelumnya dipertegas pada larik kedua dan ketiga //Bunyi nyaring panggilan, warnawarni potret wajah/variasi permainan, mereka asik sendiri// Aku lirik mendeskripsikan bahwa segala keramaian di pasar malam tersebut tidak bisa mengalihkan perhatian mereka dari telepon genggam, mereka sibuk dengan telepon genggam dan melakukan kegiatan sendiri dengan gawainya seperti menelepon, berfoto, memperbarui status media sosial, dan lainnya.

Diikuti oleh larik keempat (L4) IIbuku tak mau ketinggalan, ikut ambil bagian/ yang melengkapi deskripsi suasana pasar malam dan perasaan aku lirik saat memperhatikan tokoh ibu. Frasa ikut ambil bagian dengan jelas menunjukkan sindiran aku lirik kepada tokoh ibu yang ikut sibuk memperhatikan telepon genggamnya. $\mathrm{Aku}$ lirik menceritakan bagaimana suasana pasar malam dan sikap orangorang yang ada di dekatnya.

Di sisi lain, aku lirik sendiriyang memperhatikan mereka satu persatu - seolah tidak melakukan apa pun dan kehilangan perhatian. Sebagaimana ungkapan aku lirik yang menyatakan bahwa dirinya ditinggal sendirian dan tak ada teman untuk diajak mengobrol. Ungkapan tersebut secara denotatif terdapat dalam larik pertama bait kedua di bawah ini.

Aku ditinggal sendirian, tak punya teman mengobrol (L1)(B2)

Suasana tidak mengenakan dan perasaan resah yang dialami aku lirik di atas sejatinya merupakan ungkapan yang dialami dan dirasakan juga oleh anak-anak ketika berada di antara keramaian dan kesibukan orang dewasa dengan gawainya. Tidak jarang anakanak bukan menjadi tokoh utama dari ceritanya yang semestinya menyenangkan. Tempat-tempat seperti pasar malam dan tempat wahana bermain lainnya adalah surga bagi anak-anak yang ingin bermain dengan bebas bersama orang yang disayanginya (orang tua). Namun perhatian dari orang tua tidak sepenuhnya didapatkan oleh anak karena orang-orang yang disayanginya tersebut sibuk dengan gawai. Sering kali gawai atau telepon genggam mengganggu keharmonisan dan kebahagiaan hubungan antara anak dan orang tua. Pada akhirnya anaklah yang menjadi korban dengan perasaan resah dan cemburu. Anak hanya bisa terdiam, marah, bahkan menangis terutama bagi anak-anak yang masih bayi. 
Pemanfaatan Hasil Analisis sebagai Bahan Ajar Handout dalam Pembelajaran Sastra di Tingkat SMP

Peneliti akan memanfaatkan hasil penelitian ini sebagai bahan ajar handout. Penentuan pemilihan handout sebagai luaran dari penelitian ini didasarkan pada permasalahan yang ditemukan di lapangan (sekolah), yaitu kesulitan yang dialami anak dalam memahami gaya bahasa dan minimnya bahan ajar pembelajaran sastra yang menggunakan karya penyair anak. Oleh karena itu, dalam tahap ini peneliti akan mendeskripsikan penyusunan bahan ajar handout dalam mata pelajaran Bahasa Indonesia di tingkat SMP.

Berdasarkan pemetaan materi dalam silabus mata pelajaran Bahasa Indonesia kurikulum 2013 (edisi revisi 2017), handout yang peneliti buat dapat dipergunakan sebagai penunjang materi teks puisi pada periode semester ganjil untuk siswa kelas VIII SMP/Mts. Kompetensi dasar yang peneliti pilih sejalan dengan hasil penelitian yaitu gaya bahasa dalam unsur pembangun puisi. Di samping unsur pembangun puisi secara keseluruhan, hasil analisis gaya bahasa dari penelitian ini dapat dimanfaatkan untuk siswa berlatih mengidentifikasi gaya bahasa dengan lebih mendetail. Dengan demikian, siswa diharapkan dapat memahami gaya bahasa dengan mudah sehingga tidak kesulitan dalam memahami puisi.

Pertama, peneliti melakukan analisis kurikulum berdasarkan silabus yang telah didapat dari guru Bahasa
Indonesia di SMP Negeri 2 Teluk Jambe Timur Karawang. Melihat silabus tersebut peneliti memperoleh temuan untuk kompetensi dasar yang $\begin{array}{llll}\text { digunakan yakni } & \text { KD } & 3.7\end{array}$ mengidentifikasi unsur-unsur pembangun teks puisi yang diperdengarkan atau dibaca. Adapun Indikator Pencapaian Komptensi (IPK) nya yaitu 3.7.1 Menjelaskan pengertian teks puisi dan 3.7.2 Menganalisis unsur-unsur pembangun puisi.

Dari temuan analisis kurikulum tersebut, diketahui bahwa materi yang sesuai dengan hasil penelitian yaitu materi teks puisi periode semester ganjil untuk siswa kelas VIII SMP/Mts. Kedua, handout berjudul "Pesona Puisi" yang telah disesuaikan dengan KD dan materi teks puisi mata pelajaran Bahasa Indonesia. Selanjutnya peneliti menyusun identitas handout sebelum masuk ke teori atau materi pembelajaran. Perihal materi, peneliti menggunakan buku referensi yang dapat dipertanggungjawabkan. Dalam materi disisipkan dua puisi yang merupakan hasil analisis dari peneliti.

Puisi Mata Air Surga karya Aulia Murti peneliti jadikan contoh materi, sedangkan puisi Doa Sapi karya Muhammad de Putra dijadikan puisi yang diidentifikasi dalam tugas siswa. Ketiga, referensi yang digunakan peneliti sebagai bahan penulisan terdiri dari berbagai sumber, di antaranya buku dari Kemdikbud, buku teori puisi, buku teori diksi dan gaya bahasa, serta buku kumpulan puisi. Keempat, sebagaimana jenjang siswa SMP, maka 
dalam penyusunan kalimatnya peneliti menggunakan kurang lebih 3-5 kalimat sederhana dalam satu pemaparan teori. Kelima, peneliti telah diberikan masukan oleh dosen ahli dan guru Bahasa Indonesia di SMP untuk bahan evaluasi handout. Dan keenam, peneliti menggunakan sumber belajar lain berupa tautan internet dan youtube sebagai upaya memperkaya materi handout.

\section{SIMPULAN}

Setelah menganalisis dan mendeskripsikan temuan, ditemukan 53 bentuk dari 12 jenis gaya bahasa retoris. Dari total keseluruhan 23 jenis gaya bahasa retoris, 12 jenis yang ditemukan di antaranya yaitu aliterasi, asonansi, anastrof, asindenton, eufemismus, litotes, perfrasis, prolepsis, erotesis, koreksio, hiperbol, dan paradoks. Aliterasi menjadi jenis dengan penggunaan terbanyak dalam puisi yaitu 10 bentuk. Diikuti oleh tujuh erotesis, enam asonansi, enam anastrof, enam perifrasis, empat hiperbol dan paradoks, tiga litotes dan asindenton, dua prolepsis, serta koreksio dan eufismus yang masingmasing satu bentuk.

Gaya bahasa kiasan dalam sepuluh karya dari lima penyair anak juga telah dianalisis oleh peneliti. Hasilnya, penggunaan kiasan jauh lebih banyak dibandingkan retoris. Dengan total 80 bentuk berasal dari 11 jenis gaya bahasa kiasan. Adapun 11 jenis yang terdapat dalam puisi penyair anak yaitu: simile, metafora hidup dan mati, alegori, personifikasi, fabel, epitet, sinekdoke, metonimia, hipalase, ironi, dan sinisme. Di antara sebelas jenis gaya bahasa kiasan dalam karya lima penyair anak, jenis yang paling mendominasi yaitu metafora hidup sebanyak 22 bentuk. Secara berurutan diikuti oleh gaya bahasa kiasan lainnya yaitu tujuh belas simile, dua belas personifikasi, delapan metafora mati, lima sinisme, empat metonimia, tiga epitet dan alegori, dua ironi dan hipalase, sinekdoke dan fabel yang masing-masing hanya ada satu bentuk.

Hasil analisis penelitian ini juga dapat dimanfaatkan dalam pembelajaran sastra bagi anak. Sebagaimana usia para penyair anak, puisi-puisinya juga tepat dipelajari oleh anak usia 6-16 tahun. Satu di antaranya ialah anak-anak yang duduk di bangku sekolah menengah pertama. Oleh karena itu, luaran dari hasil penelitian ini digunakan sebagai bahan ajar handout dalam pembelajaran sastra di SMP.

\section{REFERENSI}

Ati, R.M.S.W. (2015). Teman Kecil. Lampung: Penerbit BE PRESS.

Faiz, A. (2004). Guru Matahari. Bandung: DAR! Mizan.

Jamela, A. G. (2020). Resep Membuat Jagat Raya. Yogyakarta: Penerbit Gorga.

Keraf, G. (2010). Diksi dan Gaya Bahasa. Jakarta: Gramedia.

Moleong, J. L. (2007). Metodologi Penelitian Kualitatif. Bandung: PT. Remaja Rosdakarya.

Murti, A. (2012). Mata Air Surga. Jakarta: Penerbit Bukupop. 
Nurgiyantoro, B. (2017). Stilistika. Yogyakarta: UGM Press.

Prastowo, A. (2012). Panduan Kreatif Membuat Bahan Ajar Inovatif. Yogyakarta: DIVA Press.

Undang-Undang Republik Indonesia Nomor 35 Tahun 2014 tentang Perubahan atas Undang-undang Nomor 23 Tahun 2002 tentang Perlindungan Anak. Lembaran Negara RI Tahun 2014.

Pradopo, R. D. (2014). Pengkajian Puisi. Yogyakarta: UGM Press.

Putra, M. D. (2017). Hikayat Anakanak Pendosa. Yogyakarta: Penerbit Gambang.

Rachmadani, F. D. (2017). Analisis Penggunaan Gaya Bahasa pada Puisi Siswa SMA di Yogyakarta. Skripsi Tidak Dipublikasikan. Fakultas Bahasa dan Seni, Universitas Negeri Yogyakarta.

Sarumpaet, R. K. (2010). Pedoman Penelitian Sastra Anak: Edisi Revisi. Jakarta: Pusat Bahasa.

Wellek, R. \& Warren, A. (2016). Teori Kesusastraan. Diterjemahkan Melani Budianta. Jakarta: Gramedia. 